\title{
MANAGEMENT MODEL WITH BY IN MODEL PENGELOLAAN DENGAN \\ PELIBATAN MASYARAKAT ADAT PADA KAWASAN TAMAN NASIONAL RAWA AOPA KABUPATEN BOMBANA
}

\author{
Jabalnur dan Nur Intan \\ The School of Law, University of Halu Oleo, Kendari, Indonesia
}

\begin{abstract}
Abstrak
Tujuan penelitian ini yaitu mengidentifikasi kawasan Taman Nasional Rawa Aopa yang merupakab bagian wilayah masyarakat adat Moronene Hukaea Laea dan merumuskan model pengeloaan dengan pelibatan masyarakat adat sebagai pelestarian kearifan local pada kawasan Taman Nasional Rawa Aopa. Berdasar hasil penelitian tersebut dapat dijadikan indikator dan acuan dalam mengatasi permasalahan dalam pengelolaan kawasan taman nasional.

Metode yang digunakan dalam penelitian ini yaitu tipe penelitian deskriptif kualitatif dengan pendekatan normatif empiris karena dianggap paling tepat untuk merumuskan model pengelolaan dengan pelibatan masyarakat adat pada kawasan Taman Nasional Rawa Aopa dengan mengacu pada peraturan perundang-undangan yang mengatur tentang pengelolaan kawasan taman nasional serta menganalisis fenomena yang ada di lapangan sehingga akan diperoleh suatu strategi dalam pengelolaan taman nasional.
\end{abstract}

Kata Kunci : Pengelolaan, Masyarakat Adat, Kawasan Taman Nasional 


\title{
VOLVING INDIGENOUS PEOPLE IN THE NATIONAL PARK AREAS OF RAWA AOPA BOMBANA DISTRICT
}

\author{
Jabalnur and Nur Intan
}

The School of Law, University of Halu Oleo, Kendari, Indonesia

\begin{abstract}
The purpose of this research is to identify Rawa Aopa National Park area which is part of indigenous community of Moronene Hukaea Laea and to formulate model of management by involving indigenous community as preservation of local wisdom in Rawa Aopa National Park area. Based on the results of the study, it can be used as indicators and references in overcoming problems in the management of the park area.

The method used in this research was the type of descriptive qualitative research with the empirical normative approach. Since it is considered most appropriate to formulate the management model with the involvement of indigenous peoples in the area of Rawa Aopa National Park with reference to legislation regulating the management of national park area and analyze the phenomenon that exist in the field, so that it will obtain a strategy in the management of national parks.
\end{abstract}

Keywords: Management, Indigenous Peoples, National Park Area 


\section{LATAR BELAKANG}

Pelestarian hutan dan khususnya pengelolaan sumber daya alam atau hutan oleh masyarakat lokal pada dasawarsa terakhir ini banyak di bicarakan oleh berbagai kalangan. Hal tersebut disebabkan oleh kurang berhasilnya upaya pemerintah dalam mengelola sumber daya hutan pada masa lalu. Pada masa itu pemerintah atau badan-badan pembangunan dalam menetapkan berbagai kebijakan yang berhubungan dengan pengelolaan sumber daya hutan kurang memberi perhatian terhadap pola-pola pengelolaan secara tradisional yang lazim dipraktikkan oleh masyarakat setempat.

Salah satu alasan kurangnya perhatian pemerintah terhadap pola-pola pengelolaan sumber daya alam atau hutan secara tradisional adalah adanya anggapan bahwa pola-pola tersebut bersifat boros dan tidak efisien, khususnya di daerah tropis. Agar pengelolaan hutan (eksploitasi, penggunaan dan pemasaran hasil hutan, reboisasi dan rehabilitasi) dapat dilakukan secara maksimal dengan berlandaskan asas kelestarian, maka hutan seharusnya diselenggarakan oleh pemerintah, baik pusat maupun daerah.

Konstitusi Indonesia menjamin bahwa negara mengakui dan menghormati kesatuan-kesatuan masyarakat hukum adat beserta hak-hak tradisionalnya sepanjang masih hidup dan sesuai dengan perkembangan masyarakat dan prinsip Negara Kesatuan Republik Indonesia, yang diatur dalam undang-undang. Pengelolaan oleh masyarakat adat seperti dalam pengelolaan hutan. Dasar hukum pengaturan hutan di Indonesia yaitu UU Nomor 41 Tahun 1999 tentang Kehutanan yang telah diubah melalui UU Nomor 19 Tahun 2004 Tentang Penetapan PERPU Nomor 1 Tahun 2004 tentang Perubahan UU Nomor 41 Tahun 1999 tentang Kehutanan.

Keluarnya Putusan Mahkamah Konstitusi Nomor 35/PUU-X/2012 yang menguatkan status hutan adat dimana hutan adat dipisahkan dari hutan negara maka pemerintah perlu menjamin kepastian legal untuk hak-hak masyarakat hukum adat atas hutan adatnya dalam rangka menjamin kesejahteraan bagi masyarakat hukum adat, seperti yang dicita-citakan dalam Konstitusi. Selama ini instrumen hukum yang ada belum mampu menjamin keberlangsungan masyarakat hukum adat dengan hutan adatnya. UU Nomor 41 Tahun 1999 tentang Kehutanan telah memisahkan hutan adat dari masyarakat hukum adat melalui konsep hutan Negara. Hal ini oleh pemerintah berakibat pada kerentanan masyarakat 
hukum adat dalam menjamin kesejahteraan mereka dan keberlanjutan ekologis hutan.

Adanya putusan MK tersebut tentang pengakuan hutan adat telah membangkitkan semangat baru dalam advokasi pemulihan penguasaan hutan oleh masyarakat hukum adat. Putusan tersebut dianggap sebagai salah satu wujud perjuangan masyarakat hukum adat atas hutan adatnya. Hutan adat, sebagaimana dinyatakan dalam Putusan MK Nomor 35/PUU-X/2012 tidak lagi bagian dari hutan negara. Hutan adat menjadi bagian dari hutan hak masyarakat hukum adat.

Pasca keluarnya putusan MK tersebut berpengaruh pada kawasan-kawasan hutan masyarakat adat yang ternyata berada pada kawasan-kawasan yang telah mendapat penetapan pemerintah seperti kawasan Taman Nasional Rawa Aopa, dimana sebagian dari kawasan tersebut merupakan wilayah hutan atau tanah adat Suku Moronene Hukae Laea yang merupakan suku asli di Kabupaten Bombana Provinsi Sulawesi Tenggara.

Olehnya sangat diperlukan suatu model pengelolaan kawasan Nasional Rawa Aopa dengan pelibatan masyarakat adat. Masyarakat adat di Indonesia perlu dipahami sebagai komunitas-komunitas yang memiliki kearifan lokal hubungan yang kuat dengan tanah, wilayah dan sumber daya dan mereka mempergunakan tradisi sebagai alat untuk menghadapi kekuatan dominan yang menciptakan situasi ketidakadilan dalam kehidupan mereka.

\section{PERUMUSAN MASALAH}

Berdasarkan latar belakang di atas dapat angkat permasalahan yaitu belum adanya pelibatan masyarakat adat dengan kearifan lokalnya dalam konsep pengelolaan terhadap kawasan-kawasan yang dianggap sebagai tanah Negara namun sebenarnya terdapat pula kewenangan masyarakat adat di dalamnya.

Untuk itu perlu dilakukan penelitian untuk merumuskan model pengelolaan dengan pelibatan masyarakat adat sebagai upaya pelestarian kearifan lokal pada Kawasan Taman Nasional Rawa Aopa Kabupaten Bombana.

\section{TUJUAN PENULISAN}

Adapun yang menjadi tujuan penelitian yaitu pertama, mengidentifikasi kawasan Taman Nasional Rawa Aopa yang merupakan bagian wilayah masyarakat adat Moronene Huka'ea La'ea.

Kedua, merumuskan model pengelolaan dengan pelibatan masyarakat adat sebagai pelestarian kearifan lokal pada kawasan Taman Nasional Rawa Aopa 
sehingga dapat dijadikan indikator dan acuan dalam mengatasi permasalahan dalam pengelolaan kawasan konservasi negara.

\section{MANFAAT PENELITIAN}

\section{Secara Teoritis}

Sesuai dengan perkembangan masyarakat dewasa ini dengan banyak sudah diberlakukannya hukum modern, tampaknya tidak sedikit yang dapat mempertahankan eksistensinya sebagai masyarakat hukum adat di antaranya dalam bidang Kehutanan. UU Nomor 41 Tahun 1999 tentang Kehutanan mengatakan bahwa hutan merupakan kekayaan alam yang dikuasai negara (Pasal 4, ayat (1)). Penguasaan hutan oleh Negara berarti bahwa pemerintah diberikan wewenang untuk, antara lain, menetapkan status wilayah tertentu sebagai kawasan hutan atau kawasan hutan sebagai bukan kawasan hutan (Pasal 4, ayat (2)b).

Berdasarkan aturan ini sebagian besar wilayah darat di Indonesia ditetapkan sebagai kawasan hutan termasuk di dalamnya wilayah-wilayah yang diakui oleh penduduknya sebagai wilayah adat mereka. Karena di Indonesia hampir 75\% dari wilayah darat dikuasai oleh Departemen Kehutanan, Departemen inilah yang paling banyak dan langsung bersengketa dengan masyarakat adat dan terpaksa mempersoalkan keberadaan masyarakat adat dan haknya.

Di dalam setiap adat, bahasa, suku dan agama itu, terkandung sistem nilai dan sistem pengetahuan yang sudah bertumbuh ratusan bahkan ribuan tahun yang lalu ${ }^{1}$. UU Kehutanan juga mengatur hak-hak masyarakat hukum adat yang antara lain hak memungut hasil hutan, melakukan kegiatan pengelolaan hutan sepanjang tidak bertentangan dengan peraturan perundang-undangan, hak mendapatkan pemberdayaan dalam rangka meningkatkan kesejahteraannya. Masyarakat adat sangat identik dengan kearifan lokal. Kearifan lokal yang dimiliki oleh masyarakat tradisional adalah berkaitan dengan pengelolaan sumber daya alam dimana mereka hidup dan menjadikan lingkungan hidup mereka sebagai bagian integral dari pada kebudayaannya.

\section{Secara Praktis}

\footnotetext{
${ }^{1}$ Besse Sugiswati, 2012, Perlindungan Hukum Terhadap Eksistensi Masyarakat Adat di Indonesia, Perpekstif Volume XVII No. 1 Tahun 2012 Edisi Jurnal.
} 
Dalam realitasnya banyak kemudian hak-hak masyarakat adat yang terpinggirkan oleh Negara karena ketidakmampuan masyarakat adat membuktikan keberadaannya dalam pemenuhan syarat-syarat yang diberikan oleh Negara dalam rangka pengakuan keberadaan masyarakat adat. Konflik atas tanah dan sumber daya hutan yang berlarut-larut ini menimbulkan efek sosial politik dan ekonomi yang merugikan, perlu dihindari atau dituntaskan melalui pengaturan pengakuan hak masyarakat hukum adat terutama tentang wilayah masyarakat hukum adat dalam kawasan hutan negara.

Studi tentang kawasan hutan dan masyarakat adat telah banyak dilakukan namun hanya spesifikasi pada upaya memberikan pengakuan akan keberadaan hak-hak masyarakat adat, belum merumuskan tentang model yang dapat diterapkan dalam pengembangan atau konservasi kawasan hutan atau taman nasional dengan berbasis pada kearifan lokal masyarakat adat. Pengetahuan mengenai model konservasi berbasis masyarakat adat pada kawasan taman nasional atau kawasan hutan menjadi penting mengingat bahwa salah satu tujuan hukum adalah untuk mencapai kemanfaatan hukum. Aturan-aturan yang dibuat oleh negara hendaklah jangan hanya menjadi suatu simbol pengakuan negara namun hendaklah teraplikasi dalam segala bidang kehidupan negara.

\section{METODE PENELITIAN}

\section{Metode Pendekatan}

Penelitian ini menggunakan pendekatan penelitian normatif empiris. Tipe penelitian normatif merupakan suatu tipe penelitian yang menekankan pada kajian ilmu hukum dan berusaha menekankan pada kaidah-kaidah hukum yang berlaku sehubungan dengan pengelolaan dengan pelibatan masyarakat adat pada kawasan taman nasional.

\section{Spesifikasi Penelitian}

Spesifikasi penelitian ini adalah empiris dengan mengkaji ilmu hukum untuk menemukan/menganalisis kenyataan-kenyataan yang terjadi di masyarakat khususnya dalam pengelolaan taman nasional.

\section{Metode Sampling}

Metode penelitian ini menggunakan populasi dalam penelitian ini adalah Pengelola Kawasan Taman Nasional 
Rawa Aopa dan Masyarakat Adat Moronene Huka'ea La'ea sebagai pihak yang berwenang dan terkait dalam pengelolaan dan pengembangan kawasan taman nasional. Sampel dipilih secara purposive sampling yaitu untuk pengelola kawasan Taman Nasional Rawa Aopa adalah bidang yang menangani konservasi taman nasional dan untuk masyarakat adat Moronene Hukae Laea adalah tokoh-tokoh adat masyarakat adat Moronene Hukae Laea.

\section{Metode Pengumpulan Data}

a. Data Primer

Data yang diperlukan dalam penelitian ini dilakukan dengan cara penelitian langsung dari objeknya dilakukan dengan cara:

1. Observasi

Data yang diperoleh dengan cara menelaah sumber-sumber tertentu yang terkait dengan judul penelitian.

2. Wawancara

Wawancara mendalam dan Focus Group Discussion (FGD) (Mikkelsen, 2001).

b. Data Sekunder

Yaitu data yang diperoleh dari studi pustaka. Data sekunder dalam penelitian ini dikelompokkan menjadi tiga kategori yaitu:

1. Bahan Hukum Primer

Yaitu bahan hukum yang terdiri dari:

a. Undang-Undang Dasar 1945, Pasal 18b dan 28j.

b. Undang-Undang Nomor 5 Tahun 1960

c. Undang-Undang Nomor 5 Tahun 1990 tentang Konservasi.

d. Undang-Undang Nomor 41 Tahun 1999 tentang Kehutanan

e. Putusan Mahkamah Konstitusi Nomor 35/PUU-X/2012 Putusan Yang Menguatkan Status Hutan Adat Yang dipisahkan dari Hutan Negara.

f. Peraturan Daerah

Nomor 4 Tahun 2015 tentang Pengakuan Perlindungan dan Pemberdayaan Masyarakat Adat Huka'ea La'ea.

2. Bahan Hukum Sekunder 
Yaitu bahan hukum yang memberi penjelasan bagi bahan hukum primer, terdiri dari:

a. Buku-buku yang membahas tentang masyarakat adat dan pengelolaan wilayah konservasi.

b. Dokumen yang berkaitan dengan pengelolaan masyarakat adat dan konservasi.

3. Bahan Hukum Tersier

Bahan hukum yang memberi petunjuk dan penjelasan terhadap bahan hukum primer dan bahan hukum sekunder.

\section{Metode Analisis Data}

Data yang berhasil dirampungkan akan dianalisis baik pada saat penelitian sedang berlangsung maupun usai penelitian di lapangan. Teknik analisis data yang bersifat kualitatif interpretatif yang diproses melalui upaya penelaahan data, reduksi data, kategorisasi data, pemeriksaan keabsahan hingga penafsiran data

\section{HASIL \\ PENELITIAN \\ DAN \\ PEMBAHASAN}

Taman nasional Rawa Aopa telah menjadi salah satu ikon Kabupaten
Bombana sebagai aset pelestarian lingkungan. Keberadaannya sebagai taman nasional Rawa Aopa berdasar Surat Keputusan Menteri Kehutanan Tahun 1990 dengan keputusan Nomor 756/Kpts-II/1990 tanggal 17 Desember 1990 yang memiliki luas \pm 105.194 hektar. Secara administratif taman nasional ini meliputi tiga wilayah kabupaten di Provinsi Sulawesi Tenggara, yaitu Kabupaten Buton (45.605 ha), Kabupaten Kolaka (12.825 ha) dan Kabupaten Kendari (sekarang Kabupaten Konawe) (46.764 ha). Titik pertemuan ketiga wilayah ini berada di tengah kawasan Taman Nasional Rawa Aopa Watumohai yaitu dipuncak pegunungan Mendoke yang sering disebut juga Segitiga Bukari (Buton, Kolaka, Kendari).

Pada 6 Maret 2011, taman nasional ini dinobatkan dunia sebagai Situs Ramsar, yakni area lahan basah yang didedikasikan bagi konservasi. Ramsar merujuk pada sebuah kota di Iran yang menjadi tempat ditandatanganinya Konvensi Lahan Basah oleh tujuh negara. Kendati namanya asing, Rawa Aopa ternyata menjadi bagian gerakan global yang berniat menjaga kelestarian bumi ${ }^{2}$. 
Secara historis kawasan Taman Nasional Rawa Aopa merupakan penggabungan antara Taman Buru (TB) Watumohai seluas 50.000 ha dan SM Rawa Aopa seluas 55.560 ha yang ditunjuk berdasarkan SK Menteri Kehutanan Nomor 138/Kpts-II/1985. Pada tanggal 27 Juli 1985 Menteri Kehutanan dengan Keputusan Nomor 189/Kpts-II/1985 membagi TB. Watumohai menjadi Suaka Margasatwa (SM) Gunung Watumohai seluas 41.244 ha dan TB. Dataran Rumbia seluas 96.804 ha, sehingga luas keseluruhan SM menjadi 96.804 ha yang dikukuhkan dengan SK Deklarasi Taman Nasional Rawa Aopa Watumohai di Kaliurang Nomor 444/KptsII/1989. Tahun 1990. Dengan telah selesainya penataan batas luar kawasan TNRAW pada tahun 1986/1987 dan dengan telah disahkannya Berita Acara Tata Batas oleh panitia tata batas, maka Menhut menetapkan kawasan TNRAW seluas 105.194 ha melalui SK No. 756/KptsII/1990 tanggal 17 Desember 1990. Luas tersebut diperoleh dengan menggabungkan kembali TB Dataran Rumbia, SM Rawa Aopa - Gunung Watumohai dikurangi 2 buah lokasi enclave seluas $366 \mathrm{ha}^{3}$.

\footnotetext{
3 https://tnrawku.wordpress.com/2012/03/24/, akses tanggal 28 Juli 2017.
}

Taman Nasional Rawa Aopa terletak di $\operatorname{antara} 121^{\circ} 44^{\prime}-122^{\circ} 44^{\prime} \mathrm{BT} 4^{\circ} 22^{\prime}-4^{\circ} 39^{\prime}$ LS. Wilayah ini terletak di ujung Tenggara Pulau Sulawesi dengan batas wilayah yaitu di sebelah utara dengan wilayah kecamatan Tirawuta, Kabupaten Kolaka dan Kecamatan Lambuya dan Kecamatan Kendari, sebelah Timur dengan wilayah Kecamatan Lambuya dan Kecamatan Tinanggea, Kabupaten Kendari, sebelah Selatan dengan selat Tiworo dan wilayah Kecamatan Rumbia Kabupaten Buton dan di sebelah Barat dengan wilayah Kecamatan Ladongi Kabupaten Kolaka.

Ada 4 tipe ekosistem yang terdapat di taman nasional Rawa Aopa yaitu ekosistem hutan hujan tropika dataran rendah, hutan bakau, savanah dan hutan rawa. Keanekaragaman flora di dalam kawasan ini sangat menonjol, baik dalam tingkat jenis maupun genetikanya setidaknya tercatat 89 suku/famili, 257 marga/genus dan 323 jenis/spesies tumbuhan yang ada di antaranya terdapat 2 jenis yang dilindungi yaitu Damar (Agathis homii) dan Kasumeeto (Dyspyros malabarica).

Taman nasional memiliki fungsi yang sangat penting bagi kehidupan terutama dalam kaitan pelestarian lingkungan hidup. Beberapa fungsi taman nasional yaitu pemanfaatan hutan secara lestari, Pelestarian 
keanekaragaman hayati sekaligus ekosistemnya, melindungi sistem penyangga kehidupan, wahana pendidikan dan penelitian, serta memiliki fungsi sosial ekonomi yaitu dapat meningkatkan kesejahteraan penduduk yang berada di sekitar taman nasional.

Dalam kondisi bersisian dengan komunitas pendudukan tak jarang menimbulkan konflik pengelolaan antara taman nasional dengan penduduk. Di Kabupaten Bombana terdapat masyarakat adat yaitu Masyarakat Adat Moronene Huka'ea La'ea yang telah diakui dan dilindungi keberadaannya berdasarkan Peraturan Daerah Kabupaten Bombana Nomor 4 Tahun 2015 tentang Pengakuan, Perlindungan dan Pemberdayaan Masyarakat Adat Moronene Huka'ea La'ea di Kabupaten Bombana.

Orang Moronene diyakini merupakan suku tertua dan pertama yang mendiami dataran Sulawesi tenggara, saat ini mereka umumnya bermukim dan menyebar di sebelah selatan Sulawesi tenggara dan salah satu kampung (tobu) tertuanya adalah tobu Huka'ea La'ea. Menurut sebagian antropolog asal usul nenek moyang mereka berasal dari daratan Filipina yang diperkirakan mulai bermukim sejak tahun 1720. Secara administratif perkampungan
Orang Moronene meliputi 23 wilayah kecamatan yaitu 22 kecamatan di wilayah Kabupaten Bombana kecamatan di wilayah Kabupaten Kolaka. Adapun persebaran terebut yaitu:

1. Kecamatan Kabaena

2. Kecamatan Kabaena Timur

3. Kecamatan Kabaena Barat

4. Kecamatan Kabaena Utara

5. Kecamatan Kabaena Selatan

6. Kecamatan Kabaena Tengah

7. Kecamatan Poleang

8. Kecamatan Poleang Barat

9. Kecamatan Poleang Timur

10. Kecamatan Poleang Tenggara

11. Kecamatan Poleang Utara

12. Kecamatan Poleang Selatan

13. Kecamatan Poleang Tengah

14. Kecamatan Tontonunu

15. Kecamatan Rarowatu

16. Kecamatan Rarowatu Utara

17. Kecamatan Lantari Jaya

18. Kecamatan Mata Usu

19. Kecamatan Rumbia

20. Kecamatan Rumbia Tengah

21. Kecamatan Masaloka Raya

22. Kecamatan Mata Oleo

23. Kecamatan Watubangga (Kabupaten Kolaka).

Wilayah-wilayah tersebut dulunya merupakan wilayah kerajaan Moronene 
yang luasnya mencapai $3.393,67 \mathrm{Km} 2$. Kampung Huka'ea La'ea masuk dalam wilayah administratif Desa Watu-Watu Kecamatan Rarowatu Kabupaten Bombana.

Setelah tahun 1920 orang Moronene mulai banyak yang pindah dan atau dipindahkan dengan berbagai alasan di antaranya akibat bencana yang datang di antaranya. Pada tahun 1953 kampung mereka diserbu dan dikuasai gerombolan badik, pada tahun 1957 terjadi penyerangan oleh pasukan DI/TII yang mengharuskan mereka meninggalkan kampungnya. Sejak peristiwa inilah Orang Moronene mulai dipindah-pindahkan oleh pemerintah ke lokasi-lokasi pemukiman baru. Namun demikian ikatan orang Moronene dengan tanah leluhurnya tidaklah hilang, secara teratur mereka masih masuk tobu Huka'ea La'ea untuk berkebun dan juga membersihkan kuburan leluhurnya ${ }^{4}$.

Secara kewilayahan adat, wilayah masyarakat adat Moronene Huka'ea La'ea berada dalam wilayah Taman Nasional Rawa Aopa. Berdasar UU Nomor 5 Tahun 1990 tentang Konservasi Sumber Daya Alam Hayati dan Ekosistemnya, dalam wilayah konservasi tidak diperbolehkan ada aktivitas manusia. Taman Nasional sesuai

${ }^{4}$ http://indosiar.com:8080/ragam/kekerasan-di-hutan-pengelolaan-kawasan-konservasi-

indonesia_21447.html, akses tanggal 11 Juli 2017. dengan fungsinya merupakan wilayah konservasi dengan berbagai habitat flora dan fauna yang dilindungi. Olehnya pengakuan masyarakat adat Moronene Huka'ea La'ea ini pada awalnya menimbulkan keraguan untuk pengakuannya dalam bentuk peraturan daerah.

UUD 1945 sebagai landasan konstitusi tertinggi di Indonesia melalui Pasal 18 B ayat (2), Pasal 28 I ayat (3) dan Pasal 32 ayat (1) dan ayat (2) menyatakan negara mengakui dan menghormati kesatuankesatuan masyarakat hukum adat beserta hak-hak tradisionalnya sepanjang masih hidup dan sesuai dengan perkembangan masyarakat dan prinsip Negara Kesatuan Republik Indonesia, yang diatur dalam undang-undang. Hal ini yang menjadi landasan tegas bahwa keberadaan wilayah konservasi yang ditetapkan oleh negara tidak kemudian dapat menyebabkan keberadaan sebuah komunitas adat menjadi tidak diakui.

Menurut Kepala Kampo Masyarakat Adat Moronene Huka'ea La'ea ${ }^{5}$, masyarakat adat telah ada sejak dahulu, hidup dan berkembang secara turun temurun di wilayah adat mereka. Pada hakikatnya mereka tidak merasa keberatan dengan

\footnotetext{
5 Wawancara tanggal 7 Juli 2017 di Kampung Masyarakat Adat Huka'ea La'ea Kabupaten Bombana.
} 
wilayah mereka yang menjadi bagian Taman Nasional Rawa Aopa namun masyarakat adat menginginkan agar dalam pengelolaan taman nasional tetap dengan pelibatan masyarakat adat sebagai komunitas yang mendiami wilayah yang sebagian menjadi taman nasional karena wilayah itulah yang menjadi sumber mata pencaharian keseharian masyarakat adat.

Wilayah adat Kampo Huka'ea La'ea seluas 26.295,32 hektar. Luasan tersebut merupakan hasil identifikasi dan hasil dari proses hasil pemetaan partisipasi masyarakat pada tahun 2002 dan diperbaharui pada bulan Juni tahun 2004. Keseluruhan wilayah adat tersebut berada dalam kawasan TNRAW dengan klasifikasi tata kelola sebagai berikut:

1. Inalahi Pue (Hutan Inti)

Masyarakat Adat Moronene kampo Huka'ea La'ea mengenal dengan adanya wilayah yang dikeramatkan atau dalam bahasa Moronene disebut PopaliaI, dari turun temurun areal inalahi pue tersebut dilarang dikelola. Wilayah ini merupakan areal dari gunung Tawunawula yang menurut mitologi warga Huka'ea La'ea tempat turun mandi para 7 (tujuh) bidadari dari kayangan, tempat ini terdapat sumur batu 7 (tujuh) buah yang keberadaannya masih ada sampai saat ini. Mitologi 7 (tujuh) bidadari yang digambarkan dari cerita warga Huka'ea La'ea adalah pemuda bernama Ngkoheo yang bertemu 7 (tujuh) bidadari mandi di sumur batu yang kemudian si pemuda menyembunyikan pakaian salah satu dari bidadari tersebut, tawunaula yang berarti kumpulan tali yang dijatuhkan.

Hutan alam yang tidak pernah dijamah dan merupakan sumber mata air masyarakat adat Moronene Huka'ea La'ea. Hutan ini merupakan lokasi upacara dan ritual moli wonua setiap tahunnya oleh masyarakat adat Moronene di Huka'ea La'ea. Moli Wonua dilakukan untuk meminta permisi untuk masuk wilayah tersebut, dirangkaikan dengan upacara montewali wonua (pencucian kampung) inalahi pue merupakan hutan primer yang memiliki luas 4.623,44 hektar. Secara mitologi diyakini sebagai tempat bersemayamnya makhluk halus yang disebut Ntiwonua.

2. Inalahi popali dan kotoria (Hutan Penyangga)

Inalahi popalia dan inalahi Kotoria memiliki luas 2.599,50 hektar. Inalahi popalia adalah hutan keramat yang dipercaya sebagai tempat makhluk halus 
Ntiwonua. Oleh karena kepercayaan itulah inalahi popalia tersebut tidak pernah diganggu oleh manusia dari turun temurun (Binta hai Soro-Soro) serta di dalam inalahi popalia tersebut merupakan sumber mata air (Mata Bundu) serta tempat perlindungan segala jenis hewan. Ada kepercayaan dari masyarakat adat Haka'ea La'ea bahwa jika seseorang memasuki hutan tersebut tanpa sepengetahuan tetua kampung maka akan ketimpah bencana pada orang tersebut.

Inalahi kotoria adalah kelompok hutan sejenis tempat tertentu yang pernah ditempati/diolah (arti pekampoa/waworaha) baik untuk bercocok tanam maupun berburu dan meramu serta dijadikan tempat penguburan para sangia (Mokole) pemimpin yang ksatria. $\mathrm{Di}$ tempat diyakini tempat persemayaman makhluk halus (Ntiwonua) yang sering memperlihatkan wujudnya. Tempat tersebut tidak boleh diganggu oleh manusia. Masyarakat adat Huka'ea La'ea sangat menghargai tempat tersebut dan selalu menjaganya jika ada orang yang sengaja merusaknya, sehingga masyarakat adat Moronene kampo Huka'ea La'ea menyebutnya hutan/tempat keramat (kotoria). Tempat keramat tersebut (kotoria) adalah tempat peristirahatan satwa karena dirasa aman dari gangguan manusia, wilayah sebaran kotoria dapat dijumpai di beberapa daerah yaitu didaerah sampa ondibu (cabang/pertemuan sungaisungai), sebagai tempat mandi untuk berobat, di kuburan sangia wambakowu (lore) sangia wawompo'o sangia olobu meheo (Tuamba), sangia wumbu roda, sangia ambau, sangia molomo dan sangia pu'untokulo.

3. Inalahi peuma (Hutan Perkebunan)

Inalahi peuma memiliki luas 2.420,31 hektar merupakan hutan perkebunan yang sewaktu-waktu dapat diolah oleh masyarakat untuk dijadikan kebun. Sedangkan kura adalah lokasi bekas perkebunan masyarakat yang pernah diolah kemudian ditinggalkan, lokasi sebaran perkebunan tersebut dapat dijumpai di daerah seperti Hokihokio, Tinombu, Langkea, Sanggihoa, Sampe Tuwere, Laea, Tinombu, Pereua, Pokaea, Tali-Taliawa, Hukae, Watumelewe, Wambakowu, Lampinapa.

\section{Olobu (Hutan Kecil)}

Olobu Ute memiliki luas 1.077,56 hektar adalah kelompok hutan kecil 
yang ada di tengah padang dengan pepohonan yang jarang, satwa jarang dijumpai dihutan tersebut dan kadang tidak dijumpai sama sekali.

5. Kura (Perladangan)

Kura Tangka memiliki luas 1.195,34 hektar merupakan bekas kebun/ladang yang pernah diolah, kemudian pindah ke tempat yang baru. Tempat ini akan dijadikan kebun setelah perpindahan telah dilakukan di beberapa tempat, biasanya jangka waktu memanfaatkan kura tangka dilakukan selama lebih kurang 5 sampai 10 tahun atau tergantung dari kesuburan tanah.

Kura Ea adalah bekas kebun/ladang yang pernah diolah sekitar 1 sampai 10 tahun kemudian ditinggalkan dengan hamparan luas (lowo lue).

Kura Ate adalah bekas kebun yang pernah diolah dengan hamparan kecil (lowo ote) kemudian ditinggalkan 1 sampai 5 tahun.

Kura Hinuarako adalah bekas kebun yang pernah diolah dan baru tahap penanaman tiba-tiba pemilik kebun meninggal dengan terpaksa kebun tersebut tidak dapat dilanjutkan dan jika padi tersebut sudah terlanjur ditanam maka alasan tertentu padi tersebut tidak dijadikan bibit.
Kura Sailela adalah bekas kebun yang pernah diolah baru tahap perintisan (umawu) atau penebangan kayu (monea) tiba-tiba pemiliknya meninggal. Kebun tersebut harus ditinggalkan dan tidak bisa ditanami.

Tinalui adalah kebun yang sudah ditanami kemudian hasilnya dipanen kembali secara berturut-turut atau dua kali panen.

6. Tana Lapa/Lueno (Padang Savana)

Tana lapa/lueno memiliki luas 11.471,35 hektar

7. Bako (Hutan Bakau)

Bako memiliki luas 2.593,75 hektar

8. Bolo (Tambak Ikan Tradisional)

Bolo memiliki luas 92.19 hektar

Secara historis keberlangsungan etnis Moronene yang hidup dan berkembang di perkampungan tua (Tobu) Huka'ea La'ea terkesan selalu dipinggirkan oleh kebijakan pembangunan dan pengelolaan sumber daya alam selama berpuluh-puluh tahun lamanya. Terpinggirkannya etnis Moronene ini karena ruang hidupnya ditetapkan secara sepihak oleh pemerintah menjadi wilayah konservasi Taman Nasional Rawa Aopa tahun 1990. Akibat dari penetapan tersebut menimbulkan konflik kuasa pengelolaan ruang antara etnis Moronene di perkampungan tua (Tobu) Huka'ea La'ea dengan aparat pemerintah 
daerah melalui operasi Sapu Jagad pada tahun 1997 sampai dengan tahun 2002.

Hingga saat ini pengelolaan taman nasional masih sangat jauh dari sisi pengelolaan hutan oleh rakyat, karena pengertian konservasi sebagai kawasan yang 'steril' dari masyarakat masih menjadi pegangan pemerintah dalam pengelolaan hutan. Hal tersebut mengakibatkan seringnya terjadi konflik antara rakyat dengan pengelola kawasan taman nasional. WALHI mencatat bahwa hingga tahun 2003 telah terjadi beberapa pengusiran rakyat dari kawasan konservasi di Indonesia, di antaranya di TN Lore Lindu, TN Kutai, TN Meru Betiri, TN Komodo, TN Rawa Aopa Watumoi, TN Taka Bonerate, TN Kerinci Seblat dan beberapa kawasan lainnya.

Konflik-konflik pengelolaan yang masih terjadi pada Taman Nasional Rawa Aopa disebabkan antara lain:

1. Belum adanya pemetaan wilayah yang secara jelas menunjukkan luas batasan wilayah masyarakat adat dan luas batasan wilayah konservasi.

Perda Nomor 4 Tahun 2015 pada Pasal 6 mengatur bahwa:

(1) Pemerintah Daerah mengakui wilayah adat masyarakat Adat Moronene Huka'ea La'ea.
(2) hanya mengatur bahwa yang dimaksud wilayah adat Masyarakat Moronene Huka'ea La'ea adalah keseluruhan wilayah Masyarakat Adat Moronene Huka'ea La'ea yang meliputi darat dan perairan berdasarkan hak-hak komunal masyarakat.

(3) Wilayah adat masyarakat adat Moronene Huka'ea La'ea sebagaimana ayat (2) terdiri dari:
a. Inalahi Pure (Hutan Inti)
b. Inalahi Popalia (Hutan Penyangga)
c. Inalahi Puema (Hutan Perkebunan)
d. Olobu (Hutan Kecil)
e. Kura (Padang)
f. Lueno (Padang)
g. Bako (Bakau)
h. Beo (Tambak Garam)
i. Bolo (Tambak Ikan Tradisional).

(4) Luas wilayah adat dan batas-batas wilayah adat masyarakat Moronene Huka'ea La'ea, akan diatur lebih lanjut setelah ada kesepakatan bersama 3 (tiga) Kementerian yakni Kementerian Dalam Negeri RI, Kementerian Kehutanan RI, Kementerian Pekerjaan Umum dan 
Kepala Badan Pertanahan Nasional

RI.

Perda ini belum mengatur secara spesifik batas wilayah yang merupakan wilayah adat masyarakat Moronene Huka'ea La'ea, termasuk berapa luas wilayah adat yang menjadi bagian taman nasional Rawa Aopa.

2. Masih terdapatnya kelompok-kelompok masyarakat yang secara ilegal memasuki wilayah taman nasional dan melakukan kegiatan pertanian namun tidak ada pengawasan atau tindakan tegas dari pihak balai taman nasional untuk menindak hal tersebut. Kehadiran kelompok-kelompok masyarakat yang melakukan pengolahan tanah di wilayah taman nasional menjadi sebuah keprihatinan bagi masyarakat adat Moronene Huka'ea La'ea. Aturan adat masyarakat Moronene Huka'ea La'ea tidak memperbolehkan adanya orang asing (di luar dari masyarakat Moronene yang mendiami wilayah adat) untuk mengolah dan mengambil manfaat dari tanah masyarakat adat untuk kegiatan apa pun. Tidak adanya penanganan terhadap orang-orang yang menggarap tanah di seputar taman nasional menimbulkan kekhawatiran akan berkurangnya luas tanah adat.

3. Adanya orang-orang yang ingin memperoleh tanah dengan hak penguasaan individu (hak milik) pada wilayah-wilayah masyarakat adat yang juga menjadi wilayah taman nasional. Potensi alam yang sangat besar pada kawasan taman nasional yang termasuk wilayah masyarakat adat Moronene Huka'ea La'ea telah banyak menjadi incaran atau peminatan dari para pemilik modal untuk bisa menguasai atau mengolah tanah-tanah masyarakat adat. Aturan adat yang mengikat masyarakat adat tentang larangan pengalihan tanah adat telah menjaga kelestarian tanah terutama dari tindakan-tindakan yang akan mengarah pada perusakan lingkungan hidup seperti kegiatan pertambangan atau perambahan hutan.

Pelibatan masyarakat adat dalam pengelolaan Taman Nasional Rawa Aopa adalah sangat penting karena wilayah masyarakat hukum adat berada dalam kawasan taman nasional tersebut. Model pengelolaan dengan pelibatan masyarakat adat tersebut karena kawasan masyarakat hukum adat Huka'ea La'ea selama ini tetap terjaga kelestariannya dan tidak terambah 
oleh masyarakat luar dibandingkan dengan kawasan lain yang pada beberapa bagian dikelola oleh masyarakat luar yang melakukan kegiatan perkebunan dalam wilayah taman nasional.

Pengetahuan tradisional masyarakat adat Moronene Huka'ea La'ea dalam pengelolaan sumber daya alam di kampo Huka'ea La'ea telah ada dan berlangsung sejak nenek moyang mereka yang diwariskan secara turun temurun kepada generasinya. Hal ini sebagaimana dikemukakan oleh beberapa orang tokohnya dan diakui oleh penduduk lainya. Faktafakta yang menunjukkan masih berfungsinya beberapa model kearifan tradisional pada masyarakat adat Moronene di kampo Huka'ea La'ea adalah pengelolaan hutan tradisional yang mampu melindungi berbagai ekosistem dan keanekaragaman hayati (flora dan fauna) yang ke semuanya diatur dalam peraturan adat termaksud sanksi-sanksi dalam kerangka melindungi dan mengelola sumber daya alam secara bijaksana.

Kawasan hak-hak tradisional dalam kaitannya dengan hak dan akses atas sumber daya alam yang diatur yang diatur dan ditetapkan atas kedaulatan adat Moronene hingga sekarang masih ada walaupun sebagian besar sudah tidak dikelola/terawat di kampo Haka'ea La'ea. Fakta-fakta ini sekalipun membantah tuduhan dari pihak luar akan ketidakmampuan model tradisional dalam mengelola dan memanfaatkan SDA yang lestari dan berkelanjutan.

Dalam pengelolaan SDA seperti hutan, bagi masyarakat adat Moronene di kampo Huka'ea La'ea, hutan adalah bagian yang tak terpisahkan bagi kelangsungan kebudayaan dan adat istiadat mereka yang merupakan juga simbol kultur/kebudayaannya yang terus dimanfaatkan oleh komunitas adat Moronene di kampo Huka'ea La'ea.

Fungsi hutan bagi komunitas adat Moronene di kampo Huka'ea La'ea sangat berarti dan mendasar serta mempunyai ketergantungan, upaya yang dilakukan bagi masyarakat adat kampo Huka'ea La'ea secara turun temurun yang diwariskan kepada generasinya adalah dengan tetap berpegang teguh pada upaya melindungi dan mengelola hutan berdasarkan prinsip keadilan yang berkelanjutan. Hal ini didukung dan diperkuat dalam lembaga/pranata adat.

Kearifan tersebut tergambar dari cara masyarakat adat Moronene Huka'ea La'ea mengelompokkan jenis-jenis hutan yang dapat dimanfaatkan secara langsung maupun 
tidak langsung. Pengelompokan hutan dan perkebunan serta pemanfaatannya secara lokal dikenal dengan nama inalahi pue inalahi popalia/kotoria, inalahi peumaa/kura. Begitu halnya pengelompokan hutan yang berada di sekitar atau di tengah padang rumput (olobu). Secara lokal dikenal dengan nama olobu E'a, olobu ute, olobu popalia.

Demikian pula dalam pengelolaan kebun dimana masyarakat hukum adat Moronene Huka'ea La'ea adalah masyarakat agraris. Pemanfaatan SDA tersebut dilakukan dengan cara membuka lahanlahan perkebunan untuk pemenuhan kebutuhannya. Pembukaan lahan untuk perkebunan merupakan tradisi masyarakat adat Moronene Huka'ea La'ea. Pembukaan lahan secara berpindah-pindah merupakan tradisi secara turun temurun. Akan tetapi pembukaan lahan perkebunan secara berpindah-pindah tersebut diatur dalam peraturan ada.

Masyarakat Moronene Huka'ea La'ea membagi pembukaan lahan perkebunan tersebut dengan klasifikasi:

1. Kura Tangka merupakan bekas kebun/ladang yang pernah diolah, kemudian pindah ke tempat yang baru. Tempat ini akan jadi dijadikan kebun setelah perpindahan telah dilakukan di beberapa tempat, biasanya jangka waktu memanfaatkan Kura Tangka dilakukan selama kurang lebih 5 sampai 10 tahun atau tergantung dari kesuburan tanah.

2. Kura'ea adalah bekas kebun/ladang yang pernah diolah sekitar 1 sampai 10 tahun kemudian ditinggalkan dengan hamparan luas (lowo Lue)

3. Kura eta adalah bekas kebun yang pernah diolah dengan hamparan kecil (lowo Ote) kemudian ditinggalkan 1 sampai 5 tahun

4. Kura Hinuarako adalah bekas kebun yang pernah diolah dan baru tahap penanaman tiba-tiba pemilik kebun meninggal dengan terpaksa kebun tersebut tidak dapat dilanjutkan dan jika padi tersebut sudah terlanjur ditanam maka dengan alasan tertentu padi tersebut padi tidak bisa dijadikan bibit.

5. Kura Sailela bekas kebun yang pernah diolah baru tahap rintisan (Umawu) atau penebangan kayu (Monea) tiba-tiba pemiliknya meninggal. Kebun tersebut harus ditinggalkan dan tidak bisa ditanami.

6. Tinalui adalah kebun yang sudah ditanami kemudian hasilnya dipanen kembali secara berturut-turut atau dua kali panen.

Selanjutnya dalam perlindungan satwa dimana satwa merupakan kebanggaan 
masyarakat adat Moronene Huka'ea La'ea yang perlu dijaga dan dilestarikan agar tidak punah dari habitatnya. Masyarakat adat Moronene Huka'ea La'ea sangat menghargai kehidupan satwa yang ada di sekitarnya. Keberadaan satwa dimanfaatkan secara bijaksana. Oleh karena itu proses perburuan satwa diatur agar tidak menimbulkan ketimpangan alas sekitarnya.

Perburuan satwa secara turun temurun masyarakat adat Moronene Huka'ea La'ea hingga sekarang. Akan tetapi perburuan satwa hanya dilakukan pada satwa-satwa tertentu dan pada waktu tertentu. perburuan satwa seperti rusa dan anoa yang diburu adalah rusa dan anoa yang sudah dewasa dan dipastikan dalam keadaan tidak hamil. Waktu perburuan hanya diperbolehkan pada malam hari dan hanya dilakukan sekali dalam tiga bulan.

Kesatuan sebagai masyarakat hukum adat maka sifat penguasaan dan pengelolaan tanah di wilayah adat masyarakat adat Moronene Huka'ea La'ea tidak mengenal kepemilikan secara individual. Seluruh wilayah adat merupakan bersifat komunal. Tanah-tanah yang dikuasai dan dikelola oleh masing-masing anggota masyarakat adat Moronene Huka'ea La'ea hanya untuk kepentingan pemenuhan kebutuhan pokok anggota masyarakat adat.
Setiap anggota masyarakat adat Moronene Huka'ea La'ea diberikan lahan oleh lembaga adat untuk digarap dan dimanfaatkan secara turun temurun. Lokasi dan luas lahan masing-masing anggota masyarakat adat Moronene Huka'ea La'ea ditentukan berdasarkan musyawarah adat. Lahan yang dimanfaatkan atau dikelola selama 2 tahun akan diambil oleh lembaga adat dan diberikan hak kelolanya kepada masyarakat adat Moronene Huka'ea La'ea lainnya melalui musyawarah adat. Pengelolaan lahan dan pemanfaatan sumber daya alam di sekitarnya dilakukan secara tradisional berdasarkan pengetahuan yang dimilikinya dan menjadi kebiasaan yang dianut dalam masyarakat adat Moronene Huka'ea La'ea.

\section{KESIMPULAN DAN SARAN}

\section{A. Kesimpulan}

Model pengelolaan dengan pelibatan masyarakat adat pada Taman Nasional Rawa Aopa adalah Mengakui dan menerapkan kearifan lokal masyarakat adat Huka'ea La'ea dalam pengelolaan wilayahnya yaitu dalam pengelolaan hutan, perlindungan satwa, pengelolaan lahan garapan dan pemanfaatan sumber daya alam.

\section{B. Saran}

1. Agar masyarakat adat dapat mengelola dan menjaga wilayah 
masyarakat adatnya perlu dilakukan pemetaan dan penetapan secara

jelas dan tegas batas kawasan

taman nasional dan kawasan

wilayah masyarakat adat Huka'ea

La'ea.

2. Membutuhkan peran pemerintah untuk mengakui, melindungi, dan melakukan pemberdayaan masyarakat adat Moronene Huka'ea La'ea.

\section{DAFTAR PUSTAKA}

\section{Buku-buku}

Besse Sugiswati, 2012, Perlindungan Hukum Terhadap Eksistensi Masyarakat Adat di Indonesia, Perpekstif Volume XVII No. 1 Tahun 2012 Edisi Jurnal

\section{Internet}

http://basecamppetualang.blogspot.co.id/201 5/09/.html, akses tanggal 20 Juli 2017.

https://tnrawku.wordpress.com/2012/03/24/, akses tanggal 28 Juli 2017.

http://indosiar.com:8080/ragam/kekerasandi-hutan--pengelolaan-kawasan-konservasiindonesia_21447.html, akses tanggal 11 Juli 2017. 